\title{
YLIOPISTOPEDAGOGISEN ASIANTUNTEMUKSEN JÄLJILLÄ
}

\begin{abstract}
Yliopiston tärkein olemassaolon oikeutus on ollut tiedon tuottaminen, ja tieto itsessään on yliopistoinstituution päämääränä. Tieto itseisarvona on kuitenkin ammentunut legitimaatiolähteenä tyhjiin. Jälkiteollisessa yhteiskunnassa yliopisto on menettänyt asemansa tärkeimpänä tiedon tuottamisen ja jakamisen instituutiona, väittää aikamme tunnettu sosiologi, professori Gerard Delanty. Artikkelissa pohdiskellaan yliopistoa tietoinstituutiona yliopistopedagogiasta ja sen uudistumisesta käsin. Pedagogisen reformin vaikeus on kuitenkin kulttuurisen muutoksen vaikeudessa, kirjoittaja toteaa.
\end{abstract}

\section{ESA POIKELA}

Y iopisto on yksi ihmiskunnan tärkeimpiä instituutioita. Sen tehtävästä on keskusteltu humanistisen sivistyksen ja tuotannollisen hyödyn, tieteellisyyden ja ammatillisuuden sekä koulutuksen ja työn välisessä jännitekentissä. 1900-luvun yliopistoinstituution kehityssuuntana on ollut lisääntyvä sekularisoituminen (Delanty 1998) ja kompleksisuus (esim. Barnett 2000). Uusia jännitteitä on viritelty ideaalin tutkimusyliopiston ja arkisen opetusyliopiston välillä, mikä on tulkittavissa myös perinteisten yliopistojen ja uusien ammattikorkeakoulujen välisen työnjaon hakuna (esim. Sipilä 2000). Yliopistolain neljännessä pykälässä asetettu yhteiskunnallinen palvelutehtävä eli niin sanottu kolmas tehtävä on tuonut oman lisävärinsä keskusteluun. Niinpä yliopistoa ei voi enää tarkastella vain tutkimusta harjoittavana ja opetusta antavana instituutiona vaan siltä odotetaan aktiivista kumppanuutta erilaisissa alueellisissa, kansallisissa ja jopa globaaleissa kehitysprojekteissa.

Artikkelissani tarkastelen aluksi yliopiston institutionaalisen tehtävän muutosta ja kuvaan yliopistoa akateemisena yhteisönä, jossa tehdään tutkimusta erilaisten yhteiskunnallisten tarpeiden ja orientaatioiden perustalta ja jolta pohjalta myös "uusi” palvelutehtävä saa perustelunsa. Toiseksi tarkastelen yliopistoa käytännön yhteisönä muun muassa usean vuoden yliopistopedagogisten kurssien ohjauskokemuksen pohjalta sekä aihetta käsittelevien kirjojen (noin 50 artikkelia) kirjoittajana ja toimittajana (ks. Järvinen, Lehtovaara, Poikela, \& Viskari 1994, Poikela \& Öystilä 2001 ja 2003, Poikela 2002). Näkökulma käytännön yhteisöön rajautuukin Tampereen yliopistossa tapahtuneeseen kehittämiseen. Lopuksi pyrin löytämään yliopistopedagogisen asiantutemuksen pe-

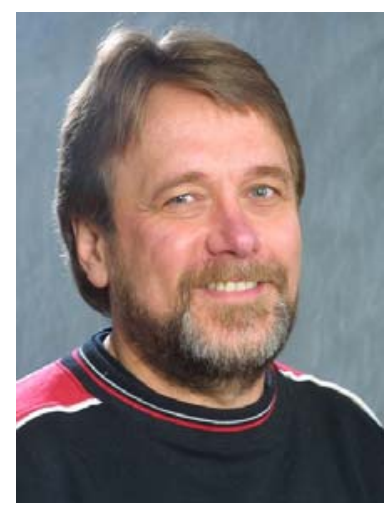

Esa Poikela rusteita en niinkään tutkimuksen ja opetuksen kuin oppimisen ja tutkimisen yhdentämisen näkökulmasta, mihin kuuluu pedagoginen myös kehittäminen.

\section{YLIOPISTON \\ INSTITUUTIONAALINEN TEHTÄVÄ}

Keskustelua länsimaisesta yliopistosta ja sen tehtävästä on hallinnut neljä perusdiskurssia (Symes ym.1999). Ensimmäisen diskurssin ytimenä on sivistys ja yksilön itsekehitys korkean moraalin ja eettisten ideaalien mukaisesti. Yliopistojen tulee olla vapaita tuotantoelämän vaatimuksista ja opettaa vain sitä, mikä on itsessään arvokasta ilman mitään siteitä työelämän vaateisiin. Toinen dis- 
kurssi sitä vastoin asettaa hyödyn yliopistokasvatuksen ytimeen. Mietiskelevän itsekehityksen sijasta yliopistoon kuuluu aktiivinen toiminta, jonka tarkoituksena on ihmiskunnan tarpeiden käytännöllinen huolehtiminen. Tiedolla on arvoa, koska sillä voidaan tehdä jotakin sen sijaan, että se olisi olemassa itseään varten.

Kolmas diskurssi hyväksyy kasvatuksen ja työn välisen yhteyden, jolloin koulutuksen yhtenä tavoitteena on kehittää työtoiminnan malleja ja olosuhteita. Yliopisto ei kuitenkaan kouluta vain työtä varten, vaan siltä vaaditaan kriittisyyttä kaikkea sitä kohtaan, mihin työ liittyy. Tavoitteena on sivistäminen industriaaliseen älykkyyteen sen sijaan, että tyydyttäisiin palvelemaan vain teknistä tehokkuutta. Neljännen diskurssin mukaan järkevin lähestymistapa on ensimmäisen ja toisen diskurssin synteesi, jolloin yliopistossa kyettäisiin yhdistämään koulutuksen yleissivistävät ja ammatilliset elementit mielekkäällä tavalla. Näkemys puhuu ammattisivistyksen puolesta ja kieltää minkäänlaisiin professioihin ja ammattitöihin perustuvan tiedon hierarkisuuden. (Emt.)

Kiinnostavaa diskursseissa on se, että niiden fokus on yliopiston sivistys-, kasvatus- ja koulutustehtävässä. Tutkimuksen merkitys nousee esiin tiedon kautta, sillä yliopiston tehtävänä ei ole ollut vain välittää tietoa kasvatuksen tai valistuksen hengessä vaan myös tuottaa sitä. Siihen liittyen voidaan esittää vielä viides diskurssi (Poikela 2001), joka jatkaa ensimmäisestä eräänlaisen katkoksen kautta. Sen ytimenä on yliopiston itseymmärrys omasta toiminnastaan ja suhteesta ympäröivään maailmaan (Delanty 1998). Delantyn mukaan yliopisto on toisaalta yhä kiinteämpi osa globalisoituvaa ja lokalisoituvaa yhteiskuntaa ja toisaalta se on kadottamassa jotakin arvokasta sille aikaisemmin kuulunutta. Yliopisto on ehkä lopullisesti kadottanut itseään, yksilöitä ja yhteiskuntaa kultivoivan tehtävänsä. Tieto itsessään on lakannut olemasta tarkoitus ja päämäärä kuten Delanty esittää ja mikä pahinta, vaihtoehtoa ei ole, vaan käsillä on tiedon loppuminen.

\section{YHDEN AIKAKAUDEN LOPPU...}

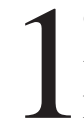
990-luvun akateeminen keskustelu kohdistui yliopiston universaalisen tehtävän lakkaamiseen globaalisten mittasuhteiden oloissa. Delanty (1998) kuvaa siirtymän Fukuyaman tapaan mutta ei niinkään historian loppuna, vaan yliopistollisen tiedon loppuna (from knowledge as an end to the end of knowledge). Yliopiston tärkein olemassaolon oikeutus on ollut tiedon tuottaminen, ja tieto itsessään on yliopistoinstituution päämääränä. Tieto itseisarvona on kuitenkin ammentunut legitimaatiolähteenä tyhjiin. Jälkiteollisessa yhteiskunnassa yliopisto on menettänyt asemansa tärkeimpänä tiedon tuottamisen ja jakamisen instituutiona.

Väitteensä tueksi Delanty esittää kuusi teesiä, joista ensimmäinen on tieteen suuren kertomuksen päättyminen. Autonominen tiede on joutunut uuden auditointikulttuurin paineeseen, mikä tarkoittaa muun yhteiskunnan tunkeutumista yliopistoon ja alistumista ulkoiseen kontrolliin. Tieteellä ei ole enää sille valistuksen filosofian osoittamaa muita instituutioita korkeampaa merkitystä, ja sen on täytynyt avautua julkiselle kritiikille ja yhteiskunnalliselle tarkastamiselle. Tulosohjauksesta on tullut kontrollin keino ja yhä suurempi osa rahoituksesta pakotetaan hankkimaan muista kuin valtion lähteistä. Niin ulko- kuin sisäpuoleltakin suoritetuista laadun arvioinneista on tullut osa jatkuvaa käytäntöä.

Toisen teesin mukaan yliopistot ovat saaneet tiedontuottajina monia kilpailijoita. Selvimmin reviirille ovat astuneet eri ministeriöiden ja elinkeinoelämän ylläpitämät tutkimuslaitokset ja -keskukset sekä ammattikorkeakoulut. Uudet polytekniset korkeakoulut eivät tyydy vain opettamiseen eivätkä edes tuotekehittelyyn, vaan haluavat "sekaantua” myös soveltavaan ja jopa perustutkimukseen. Samalla ne haluavat myös tutkintojen anto-oikeuden tohtoritutkintoja myöten. Iso-Britanniassa niin on käynytkin ammattikorkeakoulujen saatua yliopistostatuksen. Toisaalta brittiläistä yliopistoelämää sävyttävät yliopistojen väliset suuret arvostuserot ("stone and brick universities”). Suomessa yliopistojen ja ammattikorkeakoulujen välinen suhde on ollut jännitteinen alusta lähtien.

Tiedon tuottaminen ei rajaudu enää tutkimusja korkeakouluinstituutioihin, vaan tietoa tuotetaan yhä enemmän siellä, missä on toimintaakin eli yrityksissä ja työpaikoilla. Koska organisaatioiden tarvitsema tieto on paljolti konteksti- ja ongelmasidonnaista, niiden on välttämätöntä kehittää omia tiedonmuodostuksen prosessejaan. Niin sanottujen tieto- ja osaamisintensiivisten organisaatioiden lisääntyminen osoittaa selkeästi kehityksen suuntaa. Monet niistä syntyvät hyvin läheiseen yhteyteen yliopistojen kanssa ank- 
kuroituen yliopistolliseen tutkimukseen ja palvellen samalla tiedon ja innovaatioiden tarvitsijoita.

Delantyn kolmannen teesin mukaan tutkimus ja opetus ovat eriytyneet lopullisesti toisistaan. Sillä, mitä tutkitaan, ei enää ole juurikaan tekemistä sen kanssa, mitä opiskelijat tarvitsevat opiskellakseen. Tutkimus itsessään on niin spesialisoitunutta, että sitä ei voida tuoda luennoille, mistä seuraa, että tutkijat eivät ole enää kiinnostuneet opettamisesta. Opetus koetaan häiriötekijäksi, koska se on liian etäällä tutkijoiden omista intresseistä. Oman tieteenalankin sisällä on alueita, joita tutkijat eivät tunne, ja sitä pahempi, jos niitä joutuu opettamaan. Kukaan tutkimusta tekevä ei näytä olevan erityisen kiinnostunut siitä, mitä opiskelijoiden pitäisi oppia. Yksi vastaus ongelmaan onkin ollut vain opetustyötä tekeviä lehtoreiden palkkaaminen.

Neljännen teesinsä Delanty liittää yhteiskunnan ammatillisen järjestelmän kriisiytymiseen. Yliopistojen massoittuminen on perustunut koulutetun työvoiman tuottamisen tarpeeseen, mistä on seurannut opetuksen korostaminen tutkimuksen kustannuksella. Käytännössä korkeakoulutettua työvoimaa ei kuitenkaan tarvita niin paljon kuin koulutetaan. Akateemisen työvoiman tarve on pikemminkin laskeva ja siitä syystä yhteiskunnan taloudellinen rakenne ja yliopistojen tutkinnot sekä niihin liittyvä ammatillinen tarve pitäisi saada tasapainotettua. Ratkaisuna olisi ammatillisen koulutuksen peruskategorioiden laajentaminen kapeisiin erityisammatteihin kouluttamisen sijaan. Koulutusammattialojen vähetessä myös koulutettavien määrä saataisiin vähenemään.

Viidennen teesinsä Delanty perustelee tiedontulvalla, joka liittyy tiedon globalisaatioon olipa sitten kysymys alueellisesta, paikallisesta tai henkilökohtaisesta tiedosta. Esimerkkejä monimuotoisesta kehityksestä akateemisessa maailmassa ovat muun muassa elektronisessa muodossa olevan viestinnän laajeneminen ja tutkijoiden matkustelun lisääntyminen, erilaisten tutkimusverkostojen ja tutkimusryhmiin pohjautuvien julkaisujen yleistyminen, vaihto-ohjelmien vakiintuminen ja kansainvälisen rahoituksen laajentuminen. Kyse on myös nonverbaalisen viestinnän merkityksen oivaltamisesta ja haasteesta kielelliselle kommunikaatiolle. Yliopistollinen tieto ei ole enää vain yksittäisten professoreiden tuottamaa ja välittämää, vaan opiskelijat voivat hankkia tarvitsemansa tiedon periaatteessa mistä tahansa.
Delantyn kuudes teesi liittyy niin sanottuun refleksiiviseen myöhäismoderniin, millä voidaan ymmärtää yliopiston legiitimiteettiperustan murenemista ja identiteettikriisin syvenemistä. 1960luvulla syntynyt yhteiskunnallinen ja poliittinen kysymyksenasettelu on muuttunut 1990-luvulla yksilö- ja identiteettikysymykseksi. Ideologiset ongelmat ovat jääneet taka-alalle ja näyttäytyvät kulttuurisina, ikää, sukupuolta ja minuutta koskevina kysymyksinä. Samalla yliopistojen kyvykkyys ratkaista itse itseään koskevia ongelmia on asetettu kyseenalaiseksi. Esimerkiksi ulkopuoliset oikeuskäytännöt tunkeutuvat yhä selvemmin yliopistoihin. Yhteiskunta on tullut refleksiivisemmäksi suhteessa tieteentekijöiden lupauksiin eikä luota tiedeinstituution kykyyn toimia autonomisesti. Kontrolli on yhä enemmän myös median, elinkeinojen, järjestöjen ynnä muiden yhteiskunnallisten vaikuttajien asia. Esimerkiksi opiskelijoiden valituksia eivät enää aja vain opiskelijat itse vaan asianajajat ja niitä käsitellään yliopiston lautakuntien lisäksi ulkopuolisissa tuomioistuimissa.

Johtopäätöksenään Delanty kysyy, onko länsimainen yliopistoinstituutio tullut tiensä päähän, Saako asiantuntijakulttuuri lopullisen voiton intellektualismin perinteestä? Onko yliopisto vaarassa jäädä itseriittoiseksi itseään referoivaksi instituutioksi vai onko sillä jokin eettinen ja yhteiskunnallinen tehtävä? Osallistuuko yliopisto yhteiskuntaan vai tyytyykö se tarkkailemaan sitä vain ulkopuolisen roolissa? Voiko yliopisto olla kriittisesti tietoinen yhteiskunnasta ja samalla osa sen käytäntöä? Joka tapauksessa tiedon monopoli on murtunut ja yliopiston on suuntauduttava yhteiskuntaan uudella tavalla. Tiedon instituutiona yliopisto on tullut tiensä päähän eikä sitä siinä mielessä enää ole olemassa. (Emt.) Miksi sitten yliopisto-opetusta kysytään enemmän kuin koskaan aikaisemmin?

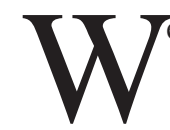

Tebster (1998) vastaa Delantylle yliopiston kvalifikaatiotehtävän näkökulmasta. Olennaisinta ei ole, että yliopisto on kadottanut tiedon monopolinsa (jos sitä on ollutkaan), vaan se, että sillä on akateemisten tutkintojen monopoli. Yliopistolla on kasvatustehtävä, jolla on merkitystä vain, jos se toteuttaa opetuksensa ja tutkimuksensa hyvin. Koska tarkastellaan vain tuloksia ja tuotoksia, on tapana, että tutkimus ja opetus asetetaan vastakkain. Seurauksena on kriittisenkin tarkastelun mystifioitu- 
minen ja yliopiston sisäisten ja konkreettisten toimintaprosessien jättäminen huomiotta. Delantyn esittämällä tavalla diskurssi hajoaa jättäen jäljelle vain tutkijoiden ja opettajien toisistaan eriytyneen arjen tai irtautuen kokonaan reaalisesta perustastaan. Vaarana on, että yliopistokeskustelu kehittyy vain itseään varten ja alkaa elää omaa elämäänsä, jos ulkoisia haasteita ja sisäisiä prosesseja ei tutkita kriittisesti (vrt. Huotari 1998).

\section{... JA TOISEN ALKU: \\ TUTKIMUKSEN JA "KOLMANNEN TEHTÄVÄN" HAASTE}

Yliopisto on akateeminen yhteisö, jonka tavoitteena on tutkia luontoa, ihmistä ja yhteiskuntaa sekä opettaa ja sivistää nuorisoa akateemiseen kansalaisuuteen. Perinteisesti tutkimus jaetaan perus-, soveltavaan - ja tuotekehitystutkimukseen. Institutionaalista rajaa halutaan vetää siten, että perustutkimus ja siihen perustuva soveltava tutkimus olisi yliopistojen yksinoikeus. Ammattikorkeakoulut voisivat tehdä tuotekehittelyä ja siihen liittyvää soveltavaa tutkimusta. Kyse on kuitenkin enemmän tutkimusrahoituksen painotuksista kuin rajan vetämisestä soveltavan tutkimuksen sisälle. Tutkimuksen haasteet ovat yhtälailla perustutkimuksen kuin uusien innovaatioidenkin kehittelyn suunnassa.

Nykypäivän yliopisto toimii neljän tutkimusorientaation luomassa jännitekentässä. Niitä ovat perinteiseksi luonnehdittava akateeminen orientaatio, teknisillä aloilla vahvasti vaikuttava markkinaorientaatio, yhteiskunnallisilla aloilla kasvava hallinnollinen orientaatio ja tärkeä, mutta haavoittuvainen kansalaisyhteiskuntaorientaatio (Hakala, Kaukonen, Nieminen \& Ylijoki 2003).

Akateemisen tutkimusorientaation lähtökohtana ovat tieteellisen uteliaisuuden, autonomian ja akateemisen vapauden ihanteet. Tutkijoiden vaikuttimina ovat keskinäisen arvostuksen ja maineen saavuttaminen tiedeyhteisön sisällä tieteellisten julkaisujen kautta. Puhtaimmillaan se ilmenee humanistisilla aloilla, joilla tutkijat pitävät kiinni henkilökohtaisesta meritoitumisesta ja tieteellisestä kunnianhimosta olosuhteiden muutoksista huolimatta.

Markkinaorientaatio palvelee yrityksiä ja kuluttajia, ja myös jotkut tutkijat kykenevät hyödyntämään tutkimustuloksia taloudellisesti. Tutkimus on yritysten ja yhtymien rahoittamaa ja tuottaa markkinoiden tarvitsemaa tietoa, sovel- luksia ja tuotekehittelyä, jolloin sitä voidaan vain harvoin pitää akateemisena perustutkimuksena. Aika-ajoin akateemisen orientaation ja markkinaorientaation välinen jännite ilmenee kiivainakin väittelyinä yliopiston tehtävästä ja asemasta kehittyvässä ja kansainvälistyvässä yhteiskunnassa.

Hallinnollinen orientaatio määräytyy pitkälle julkisen päätöksenteon esittäminä tavoitteina ja tilauksina, joilla haetaan ratkaisuja yhteiskunnallisiin ongelmiin ja kehittämistarpeisiin. Tutkimusta toteutetaan ylikansallisten ja kansallisten elimien rahoittamina projekteina, joilla ei sinänsä pyritä välittömään taloudelliseen hyötyyn vaan kehitysvaikutuksiin, joilla tuloksia saadaan pitkällä aikavälillä. Projektitutkimus ei ole myöskään ristiriidatonta suhteessa akateemiseen tutkimusorientaatioon. Tutkijoiden meritoituminen hidastuu projektista toiseen siirtymisen katkoksellisuuden ja kiireisyyden takia.

Kansalaisyhteiskuntaorientaation tavoitteena on tuottaa tietoa ihmisten käytännön elämän parantamiseksi, valtauttaa heitä omassa elämänsuunnittelussa. Ongelmana on heikko rahoituspohja verrattuna akateemiseen virkatutkimukseen, jonka varat tulevat veronmaksajilta. Kansalaisiin orientoituneet tutkijat eivät pääse osalliseksi yritysrahoituksesta, ja vain harvoin he pääsevät osalliseksi julkisen hallinnon rahoituksestakaan. (Emt., 194-197.)

Tutkimukseen kohdistetut markkinalähtöiset ja hallintoperusteiset paineet ovat tämän päivän arkea. Hankalinta asetelmassa on se, että tiedekunnat ja laitokset eivät voi tehdä 'joko tai' valintoja orientaatioiden välillä, vaan niiden on elettävä jatkuvassa 'sekä että’ tilanteessa. Ristiriidat ja jännitteet kuuluvat päätöksentekoon ja käytännön toimintaan. Ne vaativat myös institutionaalisia ratkaisuja, jolloin eri sektoreilla toimivat tutkijat ja opettajat voivat paremmin keskittyä siihen, mitä osaavat parhaiten. Ihanteellisinta olisi toimia perinteisellä akateemisella orientaatiolla, jolloin tutkijoiden riittävän valtion budjetin turvin ei tarvitsisi huolehtia taloudesta ja olisi varaa tehdä perustutkimusta sen itsensä vuoksi. Niin ei kuitenkaan ole, vaan yliopistoille on asetettu yhteiskunnallinen tilivelvollisuus tulosvaatimuksineen, jota vain pysyvissä viroissa meritoituneet tutkijat ja heistäkin vain ani harvat edes retorisesti rohkenevat vastustaa.

Australialainen tutkimus (Slaughter \& Leslie 1997) kertoo tiedelaitosten erinomaisesta sopeu- 
tumisesta markkinaorientaatioon eli ulkopuolisella rahoituksella tehdyn tutkimuksen kasvuun. Laitosjohtajien ja asemansa vakiinnuttaneiden tutkijoiden ei tarvinnut uudessa tilanteessa ottaa työtään ja menestymistään koskevia riskejä. Heistä on tullut "valtionapua nauttivia yksityisyrittäjiä” yliopiston sisälle ja projektin pettäessäkin he säilyttävät yliopistovirkansa. Sen sijaan riskit, esimerkiksi työn loppuminen tai meritoinnin viivästyminen, toteutuvat helposti projektitutkijoiden kohdalla.

Etzkowitzin ja Leydersdorffin (2000) mukaan jako akateemiseen tutkimukseen ja opetukseen on murtumassa jopa niin, että on aihetta puhua "akateemisesta vallankumouksesta”, jossa tutkimuksen ja opetuksen rinnalle nousee uutena ja kolmantena perustehtävänä yhteiskunnallinen palvelu, mikä merkitsee yritysmäisen toimintatavan hyväksymistä yliopistossa. Uusi tilanne asettaa akateemisen yhteisön pohtimaan - ei vain tutkimuksen, opetuksen ja palvelun välisiä suhteita - vaan ennen muuta identiteettiään asiantuntijayhteisönä. - Puhuminen akateemisesta vallankumouksesta tai yliopiston kolmannesta tehtävästä on nähtävä retorisena avauksena pohtia uudelleen yliopistolaitoksen velvoitteita. Mitään erityisen syvää institutionaalista muutosta ei ole näkyvissä, mutta tiedekuntien ja laitosten yksiköiden ja henkilöstön väliset suhteet ja toimivallat joudutaan neuvottelemaan uudelleen.

Institutionaalisia ratkaisuja tarvitaan, jotta yliopistotutkimus voi säilyttää perustutkimukseen liittyvän ydintehtävänsä ja samalla pysyä mukana yhteiskunnallisessa kehityksessä. Toisin sanoen markkina- tai hallintovaatimuksia ei voida torjua, mutta niihin pitää löytää paras organisationaalinen ratkaisu. Clarkin (1998) mukaan yliopistot voivat perustaa puskuri- tai välitysorganisaatioita, joissa akateemista tutkimusta ja ulkopuolisten asiakastahojen tarpeita sovitetaan yhteen. Tällaisia yksiköitä ovat esimerkiksi Työelämän Tutkimuskeskus ja Täydennyskoulutuskeskus Tampereen yliopistossa. Myös tiedekunnat ja -laitokset ovat perustaneet omia yksiköitä lähinnä siksi, että tieteenalan tutkimusyhteys pysyy paremmin kuin erillisyksikön kautta, esimerkkinä mainittakoon kasvatustieteiden tiedekunnan Eduta-instituutti Tampereen yliopistossa.

Yliopiston kolmannella tehtävällä on itse asiassa pitkä historiallinen perinne, jonka juuret ovat yliopiston laajennusliikkeenä tunnetussa toimin- nassa. Esimerkiksi Iso-Britanniassa liikkeen lähtökohtana oli 1800-luvun kansansivistystyö, jonka moderneimpana muotona on sata vuotta myöhemmin luotu Open University. Yhdysvalloissa liike sai alusta pitäen ammatillisia ja käytännön hyötytavoitteita. Australiassa yliopiston laajennusliike toteutui valtavien etäisyyksien vuoksi erilaisina etäopetuksen muotoina. Suomessa yliopistolaajennus on kehittynyt yliopistollisena kansansivistys-, kesäyliopisto- ja täydennyskoulutustoimintana. (Poikela 1983). Erityisesti 1980luvulla yliopistoihin perustettiin erillislaitoksina täydennyskoulutuskeskuksia, jotka ovat välittäneet akateemista tietoa mitä moninaisimpien koulutusohjelmien ja kehittämisprojektien muodossa yrityksille ja julkiselle hallinnolle. Täydennyskoulutuskeskukset ovatkin olleet institutionaalinen ratkaisu organisoida yhteiskunnallinen palvelutehtävä kolmen viime vuosikymmenen aikana. Sen ne ovat tehneet jopa niin tehokkaasti, että muu yliopisto on unohtanut palvelutehtävän koskaan sille kuuluneenkaan.

Kolmas tehtävä ei siis ole mikään uusi ja mullistava asia, mutta jotakin siinä on, mikä koskettaa yliopiston "kaikkein pyhintä” eli ydinprosessia, joka on enemmän kuin vain tutkimus tai opetus erikseen tai edes nämä kaksi yhdessä. Kyse ei ole vain siitä, millaisia tutkimushaasteita ja ongelmia yhteiskunnasta välittyy vaan myös siitä, miten tarvittava osaaminen tuotetaan yliopistossa itsessään. Miten akateeminen ydinosaaminen, tieteenalakohtaiset pätevyydet sekä työssä tarvittavat tiedot ja taidot opitaan ja opetetaan? Millaiselle pedagogiselle perustalle opettajat rakentavat yhteisen ja oman opetuksensa? Ohjaavatko he oppimaan ja tutkimaan vai opettavatko vain sisältöjä ja metodeja?

\section{YLIOPISTO KÄYTÄNNÖN YHTEISÖNÄ}

Nopeutuvan yhteiskunnallisen kehityksen oloissa akateemisen tiedon välittäminen vain kirjojen, tutkimusraporttien ja täydennyskoulutuksen kautta ei riitä. Yritykset, julkinen hallinto ja kansalaiset tarvitsevat tutkimista - eivät pelkästään tutkimustietoa - keskinäisen kilpailun, yhteisen kehittämisen ja henkilökohtaisen osaamisen tuottamiseen. Tutkimuksen perusteluksi ei enää riitä vain yliopistollisen tiedon tuottaminen (tutkimus) ja sen jakaminen (opetus) opiskelijoille ja muille tarvitsijoille yhteiskunnassa. Myöskään asian- 
tuntemuksen välittäminen (täydennyskoulutus) työelämälle ei riitä täyttämään osaamisen tarvetta, joka kohdistuu suoraan tiedon käyttöön eli suunnitteluun, soveltamiseen ja ongelmien ratkaisuun.

Tiedon tuottamisen ja hyödyntämisen täytyy tapahtua yhä useammin siellä, missä tutkittavat ongelmat ja kehittämishaasteet paikantuvat, toisin sanoen työelämän yksityisillä ja julkisilla sektoreilla sekä arjen todellisuudessa kansalaisyhteiskunnassa. Akateeminen työnjako, jossa tutkijat (assistentit ja professorit), opettajat (lehtorit ja yliopettajat) ja täydennyskouluttajat (suunnittelijat ja konsultit) ovat työskennelleet erikseen, ei riitä vastaamaan osaamista korostavan yhteiskunnan haasteisiin. Akateemiseen asiantuntijayhteisöön kuuluvien tulisi olla tieteenalansa asiantuntijoita ja osata tutkia, opettaa ja kehittää yliopistollisen standardin mukaan. Akateeminen identifikaatio ei rakentuisikaan pelkästään sille ajatukselle, että yhdet tutkivat, toiset opettavat, kolmannet kehittävät ja neljännet kenties johtavat. Toisin sanoen akateemisen osaamisen ytimenä olisikin yliopistopedagogisen asiantuntemuksen kehittäminen, joka pitkällä aikavälillä tapahtuisi tutkimisen, opettamisen ja kehittämistyön vaihtelun sisältämän urasuunnittelun (vrt. Järvinen 1999) puitteissa (ks. kuvio 1).

Heuristisen kuvion tarkoitus on kuvata integ- roitumista, jonka lähtökohtana on yliopiston kolme tehtävää: 1) tutkiminen, joka sisältää tutkimusryhmien johtamisen ja opiskelijoiden osallistamisen niihin, 2) opettaminen, joka tarkoittaa oppimisryhmien ohjaamista, luennointia ja harjoituksen vetämistä 3) kehittäminen, joka tarkoittaa yhteiskunnallista palvelua tarkoittaviin kehittämishankkeisiin osallistumista sekä oman tiedelaitoksen sisäistä kehittämistä.

Tutkimisen ja opettamisen toisiaan leikkaavalla alueella on kyse oppimisprosessien ohjaukses$t a$, joka perustuu siihen, että tutkiminen opitaan parhaiten tekemällä (vrt. Hakkarainen ym. 2002, Lindblom-Ylänne \& Nevgi 2003). Toisin sanoen oppijoiden tulisi voida osallistua opiskelun alusta lähtien (tutkimus)ongelmia ratkoviin ryhmiin. Siksi sekä tutkijoiden että opettajien tulisi osata ohjata sekä ryhmäprosesseja (Öystilä 2003) että yksilöllistä oppimista ongelmanratkaisun perustalta. Opettamisen kytkeminen yhteiskunnalliseen palveluun on tuottanut perinteisen täydennyskoulutuksen, jossa yhä on kyse asiantuntijatiedon välittämisestä työelämän ja muun yhteiskunnan tarpeisiin. Sen sijaan uutta on se, että työelämän organisaatiot haluavat panostaa tutkimiseen esimerkiksi niin sanotun tutkimusavusteisen kehittämisen muodossa, jolloin kyseessä on lähinnä konsultointipalvelujen tuottaminen yliopiston ulkoisia ja sisäisiä tarpeita varten.

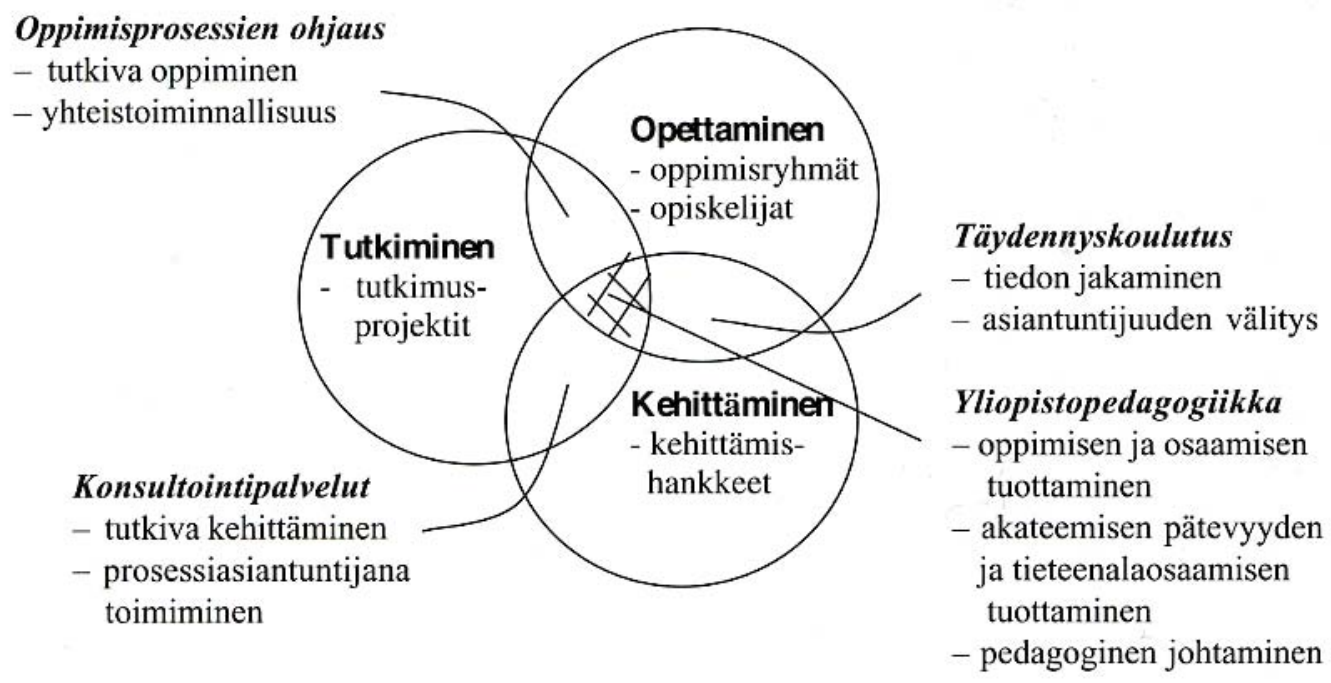


Kuvion leikkauspisteessä on yliopistopedagogiikka, joka voidaan nähdä akateemisena ydinpätevyytenä ja joka pitää sisällään tutkimiseen, opettamiseen ja kehittämiseen sisältyvän perustietämyksen ja -taitamisen. On selvää, että sellainen pätevyys voi kehittyä vain pitkän ajan kuluessa ja monipuolisen kokemuksen hankkimisen myötä. Samalla siinä tavoitetaan myös pedagogisen johtamisen erityislaatu, jonka pitäisi leimata minkä tahansa oppimista ja osaamista tuottavan instituution johtamista. Niin ajatellen yliopistopedagogiikkaa ei määriteltäisikään vain opetuksen tai edes opetuksen ja tutkimuksen näkökulman kautta vaan opiskelijoiden oppimisen ja henkilöstön työssä oppimisen (vrt. Järvinen \& Poikela 2000, 2001) ja asiantuntijuuden kehittymisen näkökulmasta.

Tieteellisen opetuksen rakennetta on aikaajoin uudistettu. Tällä kertaa meneillään on tutkintojärjestelmien harmonisointi ja standardointi niin sanotun Bolognan sopimuksen pohjalta (esim. Helle \& Ruoho 2003). Kaksiportaisen perustutkintojärjestelmän tarkoitus on luoda edellytyksiä ja mahdollisuuksia myös yliopistopedagogiikan kehittämiseen. Toisin sanoen Bolognan prosessi nostaa tieteellisen, akateemisen ja ammatillisen ydinosaamisen ja niitä tuottavat ydinprosessit tarkastelun keskiöön aivan uudella tavalla. Yliopistot ja korkeakoulut haastetaan ei vain arvioimaan vaan myös tutkimaan omia sisäisiä käytäntöjään sivistyneistön ja akateemisen työvoiman tuottajana sekä siihen tarvittavien pedagogisten prosessien laadun kehittäjinä.

Olisi siis tutkittava toisaalta sitä osaamista, mikä kantaa erilaisiin työtehtäviin ja toisaalta sitä prosessia, jolla tarvittava pätevyys saadaan aikaan. Käytäntö tulee osoittamaan uudistuksen laadun, syntyykö todella uutta osaamista eikä vain uusia puitteita vanhalle toiminnalle. Yliopistojen yksiköt, laitokset ja tiedekunnat ovat tieteen käytännön yhteisöjä (vrt. Lave \& Wenger 1991, Brown \& Duguid 2001), joissa osaaminen siirtyy yhtälailla henkilöstön työssä ja työyhteisössä oppimisen kautta kuin virallisesti määriteltyjen tavoitteidenkin kautta.

\section{HAASTEENA}

\section{YLIOPISTOPEDAGOGIIKKA}

Tieto- ja oppimisympäristöt ovat niin haastavia, että ilman keskinäistä yhteistyötä opettajat eivät kykene suunnittelemaan eivätkä ohjaamaan opis- kelua ja oppimista. Oppijoita ei voida ohjeistaa loputtoman yksityiskohtaisesti eikä myöskään luottaa heidän itseohjautuvuuteensa täydellisesti. Sen sijaan opettajalta vaaditaan yhteistoiminnallisuutta niin kollegoidensa kuin opiskelijoidenkin suuntaan. Myös vaatimus kehittämistoimintaan osallistumiseen on nähtävänä osana yliopisto-opettajan työtä, jolloin sen pitäisi näkyä henkilökohtaisten työsuunnitelmien tasolla. Käytäntöön yltävän muutoksen kohteena ei ole enempää eikä vähempää kuin koko oppimis- ja opetuskulttuurin muutos.

Yliopistoissa halutaan pitää kiinni siitä, että opettajiksi tullaan tutkija- eikä opettajakoulutuksen kautta. Eli jos on hyvä tutkija, pääsee opettamaan, mistä seuraa, että on myös kelpoinen pedagogi (esim. Ramdsen 1992). Opetusta ei kuitenkaan arvosteta samalla tavalla kuin tutkimusta ja pedagogiseen koulutukseen osallistuminen on itse kunkin henkilökohtainen asia. Koulutukseen ei myöskään kannusteta palkanlisin, vaan pelkkä palveluvuosien karttuminen on ollut tärkein palkankorotuksen peruste. Pedagogiikka mielletäänkin temppuopiksi ja koulumaisuudeksi tieteellisyyden kustannuksella (esim. Kivinen 1995, Ylijoki 1998, Honkimäki 1999, Lehto 2001, Poikela \& Öystilä 2004). Yliopisto-opettajilla on myös hyviä syitä samastua mieluummin tutkimuskuin opetusyhteisöön, esimerkiksi kiinnittyminen kansainväliseen tiedeyhteisöön koetaan tapahtuvan tutkimuksen eikä opetuksen kautta (Evans 1998).

Yliopisto-opetuksen vahvuus ei ole tutkimuksen tulosten välittämisessä kuten usein ajatellaan, vaan toimintaprosessissa, jossa tutkiminen yhdistyy oppimiseen. On jokseenkin omituista puhua tutkimuksen ja opetuksen ykseydestä kun pitäisi puhua tutkimuksen ja oppimisen ykseydestä. Tätä ykseyttä ja yhteyttä valaisee hyvin erään emeritusprofessorin tokaisu: ”yliopistossa opitaan opetuksesta huolimatta”. Jos lausumaan on edes puolittainen uskominen, syy oppimiseen löytyy muusta kuin opetuksesta. Siispä se löytyy yliopiston tarjoamasta tieto- ja oppimisympäristöstä sekä opiskelijan tutkimista muistuttavasta toiminnasta siinä. Koska oppimisen ja tutkimisen välistä yhteyttä ei ole kyettä näkemään, on syntynyt hedelmätön tutkimus- ja opetusyliopiston välinen vastakkainasettelu, joka on johtanut henkilöstöryhmien välisiin ristiriitoihin, eräänlaiseen kolmiodraamaan, jossa professorit, lehtorit ja nuoremmat tutkijat ovat vetäneet eri 
suuntiin ammatillista järjestäytymistä myöten. Onneksi askeleita kohti eheytymistä on jo otettu. Esimerkiksi tiukasta opetusvelvollisuuden laskemisesta on siirrytty kokonaistyöaikaan, joka mahdollistaa laitosten sisäisen työnjaon joustamisen myös kehittämistyön suuntaan. (Poikela 2001).

\section{JOHTOPÄÄTÖS}

$\mathrm{V}$ Time vuosien aikana on nähty voimallinen panostaminen yliopisto-opetuksen kehittämiseen, laatuun ja arviointiin, jota varten opiskelijat tuottavat palautetietoa. Arviointi johtaa parhaimmillaan kehittämistiimeihin ja toimii siten opetuksen laadun parantamisen perusteena. Heikoimmillaan se kääntyy nimettömän palautteen pohjalta tehtyyn opetuksen kontrolloinniksi, jossa hukataan tärkein eli opiskelijoiden oppimisprosessien tukeminen. Myös yliopistopedagogiikan kursseja on kehitetty ja opetussuunnitelmia on uudistettu tiedekunnissa ja tiedelaitoksilla. Pulmallista on se, että pedagogisen kehittämisen vaatimus yhä suunnataan opetustyötä tekeviin yksilöihin eikä kollektiivisen kehittämistyön tarpeita ole juurikaan kartoitettu.

Kehittäminen on vaarassa jäädä pelkäksi puheeksi, ellei sitä kohdisteta opetussuunnitelmiin ja niihin liittyvien toimintajärjestelmien uudistamiseen. Toistaiseksi vain muutamissa ammattikorkeakouluissa ja yliopistoissa on saatu aikaan selkeitä muutoksia esimerkiksi projektiopiskelun (Vesterinen 2003) ja ongelmaperustaisen pedagogiikan (Poikela, S. 2003) sovelluksina. Pedagogisen reformin vaikeus on kulttuurisen muutoksen vaikeudessa. Yksin oppimisen ja yksin opettamisen sijaan tarvitaan suuntautumista yhteistoiminnallisuuteen niin oppimisen, tutkimisen kuin pedagogisen kehittämisenkin osalta.

\section{LÄHTEET}

Barnett, R. (2000). Realizing the University. In an age of supercomplexity. The Society for Research into Higher Education \& Open University Press. Buckingham.

Brown, J.S. and Duguid, P. (2001). Knowledge and Organization: A Social-Practice Perspective. Organization Science 12: 2. 198-213.

Clark, B.R. (1998). Creating Entrepreneunial Universities: Organizational Pathways of Transformation. Guildfor: Pergamon.

Delanty, G. (1998). The idea of the university in the global era: from knowledge as an end to the end of Knowledge. Social Epistemology. 12: 1.3-25.

Etzkowitz, H. \& Leydersdorff, L. (2000). The Dynamics of Innovation: From national systems and "mode 2" to a triple helix of university-industry-government relations. $R e$ search Policy 29:2. 109-123.

Evans, C. (1988). Language People. The Experience of Teaching and Learning Modern Languages in British Universities. The Society for Research into Higher Education \& Open University Press.

Hakkarainen, K., Lonka, K. \& Lipponen, L. (2002). Tutkiva oppiminen. Älykkään toiminnan rajat ja niiden ylittäminen. WSOY.

Helle, T. \& Ruoho, I. (2003). Kaksiportainen tutkinto ja yliopistopedagogiikka. Teoksessa E. Poikela \& S. Öystilä (toim.) Yliopistopedagogiikkaa kehittämässä. Kokeiluja ja kokemuksia. Tampere University Press. 18-24.

Honkimäki, S. toim. (1999). Opetus, vuorovaikutus ja yliopisto. Jyväskylän yliopistopaino.

Huotari, V. (1998). Retrieving the university. Social Epistemology. 12: 1. 59-65.

Järvinen, A (1999). Pedagoginen asiantuntijuus ja sen kehittäminen opetus- ja ohjaustyössä. Teoksessa A. Eteläpelto \& P. Tynjälä (toim.) Oppiminen ja asiantuntijuus. Työelämän ja koulutuksen näkökulmia. WSOY.

Järvinen, A., Lehtovaara, M., Poikela, E. \& Viskari, S. toim. (1994). Oppimisen ohjaaminen yliopisto-opetuksessa. Tampereen yliopisto. Kasvatustieteiden laitos. Jäljennepalvelu.

Järvinen, A. \& Poikela, E. (2001). Modelling Reflective and Contextual Learning at Work. The Journal of Workplace Learning. Vol 13, 7/8: 282-289.

Järvinen, A. \& Poikela, E. (2000). Työssä oppimisen reflektiivisyys ja kontekstuaalisuus. Aikuiskasvatus 4/2000. 316-324.

Kivinen, O. (1995). Opetuksen, tutkimuksen ja opiskelun yhteys - kirkas utopia yliopiston harmaassa arjessa. Teoksessa M. Wiberg (toim.) Yliopisto uusiksi!. Tammer-Paino.

Lave J. and Wenger, E. (1991). Situated learning: Legitimate Peripheral Participation, Cambridge University Press. New York. 
Lehto, J. (2001). Opetustaidot eivät korvaa puutteita tieteellisessä pätevyydessä. Acatiimi 7. 25-27.

Lindblom-Ylänne, S \& Nevgi, A. toim. (2003). Yliopisto-opettajan käsikirja. WSOY.

Poikela, E. toim. (2002). Ongelmaperustainen pedagogiikka - teoriaa ja käytäntöä. Tampere University Press.

Poikela. E. (2001). Tarvitaanko yliopistossa lehtoreita? Teoksessa E. Poikela \& S. Öystilä. Tutkiminen on oppimista - ja oppiminen tutkimista. Tampere University Press. 13-29.

Poikela, E. (1983). Avoin korkeakoulu toiminnallisena ideaalina. Turun yliopisto. Hallintoviraston julkaisusarja 4/1983. Opintoasiaintoimisto.

Poikela, E. \& Öystilä, S. (2004). Oppimisen tiedettä osaajille - yliopistopedagogiikan haasteet. Teoksessa Puheenvuoroja kasvatusalan yliopistokoulutuksen kehittämisestä. Kasvatustieteiden tiedekunta, Tampereen yliopisto.

Poikela, E. \& Öystilä, S. toim. (2003). Yliopistopedagogiikkaa kehittämässä - kokeiluja ja kokemuksia. Tampere University Press.

Poikela, E. \& Öystilä, S. toim. (2001). Tutkiminen on oppimista - ja oppiminen tutkimista. Tampere University Press.

Poikela, S. (2003). Ongelmaperustainen pedagogiikka ja tutorin osaaminen. Akateeminen väitöskirja. Tampereen yliopisto. University Press.

Ramsden, P. (1992). Learning to Teach in Higher Education. Routledge. New York.

Sipilä. J. (2000). Opetusyliopistosta yliopistoksi. Rehtorin palsta. Yliopistouutiset 16.11.2000. http://www.uta.fi/ajankohtaista/index.html Tampereen yliopisto.

Slaughter, S \& Leslie, L.L. (1997). Academic Capitalism. The John Hopkins University Press. Baltimore \& London.

Symes, C., Boud, D. McIntyre, J., Solomon, N. and Tennant, M. (1999). Working knowledge: universities and 'real world' education. In Forrester, K., Frost, N., Taylor, D. and Ward, K. (eds.): Researching Work and Learning. Conference Proceedings. University of Leeds. 10-12 Sept. 1999, 426-443.

Vesterinen, P. (2003). Projektiopiskelu ja -oppi- minen ammattikorkeakouluissa. Teoksessa H. Kotila (toim.) Ammattikorkeakoulupedagogiikka. Edita Prima Oy. 79-94.

Webster, F. (1998). The idea of the university: a response to Delanty. Social Epistemology 12:1.103-113.

Ylijoki, O-H. (1994). Yliopisto-opetuksen laadun jäljillä. Yhteiskuntatieteiden tutkimuslaitoksen julkaisuja 7. Tampereen yliopisto.

Ylijoki, O-H. (1998). Akateemiset heimokulttuurit ja noviisien sosialisaatio. Vastapaino.

Öystilä, S. (2003). Toiminnallisen opetuksen perustan rakentajia - John Devey, Kurt Lewin, Jacob Levy Moreno, David Kolb ja Jack Mezirow. Teoksessa E. Poikela \& S. Öystilä (toim.) Yliopistopedagogiikkaa kehittämässä. Kokeiluja ja kokemuksia. Tampere University Press. 27-76. 